\title{
KEWENANGAN PERADILAN AGAMA DALAM MENANGANI PERKARA WARIS SETELAH BERLAKUNYA UU NOMOR 3 TAHUN 2006
}

\author{
Eka Susylawati \\ (Dosen Tetap pada Jurusan Syari ah STAIN Pamekasan dan Alumni S2 \\ Universitas Narotama Surabaya)
}

\begin{abstract}
Abstrak:
Walaupun Undang-Undang Nomor 7 Tahun 1989 tentang Peradilan Agama sudah berlaku selama hampir 17 tahun (sampai tahun 2006) pada masyarakat Muslim di Indonesia, tetapi ternyata fungsi peradilan agama dalam menangani perkara waris belumlah maksimal. Dengan berlakunya undangundang tersebut masyarakat belum dapat mengubah perilaku dari kebiasaan berperkara di pengadilan negeri kemudian beralih ke pengadilan agama. Hal ini oleh sebagian orang dianggap lumrah karena hukum waris merupakan bagian dari hukum perdata, di mana di dalam hukum perdata terdapat azas kebebasan memilih hukum. Namun apabila hal tersebut dikaitkan dengan personalitas keislaman, maka perilaku tersebut masih jauh dari harapan. Namun hak opsi dalam waris tersebut saat ini akan sulit untuk dilakukan karena UndangUndang Nomor 3 Tahun 2006 mengisyaratkan pemberlakuan hukum waris Islâm dalam sengketa waris antar orang yang beragama Islâm, sehingga tidak dimungkinkan lagi pemilihan hukum waris. Hanya saja pertanyaannya sekarang, akan effektifkah berlakunya Undang-Undang tersebut nantinya.
\end{abstract}

Kata Kunci:

Peradilan Agama, waris, hukum waris Islâm, dan hak opsi.

\section{Pendahuluan}

Negara Indonesia terdiri dari berbagai suku, agama, dan adat kebiasaan, di mana antara satu dan lainnya memiliki ciri tertentu. Perbedaan ini juga tercermin dalam tata hukum nasional yang eksistensinya sampai saat ini masih berlaku, khususnya dalam ruang 
lingkup hukum perdata, didukung oleh hukum adat, hukum Islâm dan hukum Barat.

Pluralisme dalam bidang hukum perdata tersebut merupakan konsekwensi dari salah satu norma dasar, yakni dalam pasal II Aturan Peralihan Undang-Undang Dasar 1945, yang merupakan titik

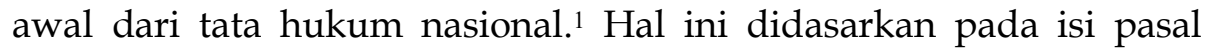
tersebut yang menyatakan bahwa segala peraturan yang ada pada waktu sebelum Indonesia merdeka, masih langsung berlaku selama belum dibuat yang baru menurut Undang-Undang Dasar.

Dari pasal II Aturan Peralihan Undang-Undang Dasar 1945, hukum produk legislatif kolonial, hukum adat, dan hukum Islâm berlaku setelah kemerdekaan. Beraneka ragamnya sistem hukum yang berlaku di Indonesia tersebut, dalam perkembangannya masyarakat mengalami pergesekan nilai-nilai yang dibawa oleh masing-masing sistem hukum. Pergesekan nilai-nilai ini membawa manusia memilih kekebasan hukum yang dirasakan menguntungkan bagi diri seseorang. Sistem hukum yang semula dirasakan adil akhirnya dianggap tidak adil dan mulai ditinggalkan. Salah satunya adalah dalam masalah warisan. Masalah ini merupakan suatu hal yang bersifat universal, di mana setiap orang dari bangsa, agama, jenis kelamin, dan status sosial mana pun akan menghadapinya.

Sebenarnya pembagian waris adalah sesuatu yang wajar, yakni setelah seseorang meninggal dunia maka hartanya akan dibagi di antara ahli waris. Masalah timbul jika terdapat ketidakpuasan terhadap jumlah harta yang akan diterima. Jalan pertama yang biasanya ditempuh adalah dengan jalur musyawarah dalam keluarga itu sendiri, baik dengan bantuan pihak ketiga ataupun tidak. Tetapi apabila jalan musyarawah tersebut tidak berhasil, maka ahli waris yang tidak puas atas bagiannya, akan mengajukan gugatannya ke pengadilan.

Masalah waris juga dapat terjadi akibat pluralisme hukum waris yang sudah diuraikan di atas, di mana pihak-pihak tunduk pada hukum waris yang berbeda. Hal ini terjadi karena masih dikenalnya pilihan hukum, yang diatur dalam Undang-Undang

\footnotetext{
1 Afdol dan Lilik Kamilah, "Pola Pembagian Waris berdasarkan Permohonan di Pengadilan Agama Surabaya dan Malang", Yuridika, Vol. 14 No. 1 (Januari-Pebruari, 1999), hlm. 45
} 
Nomor 7 Tahun 1989 tentang Peradilan Agama. Dengan adanya pilihan hukum tersebut, seorang yang beragama Islâm dapat menundukkan diri pada hukum waris adat atau waris Barat, yang notabene merupakan kewenangan pengadilan negeri.

Dengan berlakunya Undang-Undang Nomor 3 Tahun 2006 tentang Perubahan atas Undang-Undang Nomor 7 Tahun 1989, maka pilihan hukum waris bagi orang yang beragama Islâm sudah tidak ada lagi sehingga secara otomatis bagi orang Islâm berlaku hukum waris Islâm apabila hendak membagi dan menentukan ahli waris. Namun masyarakat beranggapan bahwa Undang-Undang tersebut bertentangan dengan azas kebebasan memilih hukum dalam hukum perdata.

\section{Kedudukan Hukum Waris Islâm di Indonesia}

Sebelum agama Islâm masuk ke Indonesia, masyarakat Indonesia menganut Animisme dan Dinamisme. Tetapi setelah agama Islâm dikenal, ternyata mampu mengubah pola pikir masyarakat pada waktu itu.

Sebagai akibat perkembangan yang pesat dari agama Islâm, akhirnya agama Islâm mampu menggeser kedudukan agama-agama yang ada sebelumnya (Hindu dan Budha). Hal ini dapat dibuktikan dengan banyaknya kerajaan Islâm, misalnya kerajaan Banten, Samudra Pasai, dan sebagainya. Pada kerajaan-kerajaan itu, hukum Islâm sudah merupakan hukum yang diterapkan dalam seluruh aspek kehidupan masyarakat yang memeluk agama Islâm, termasuk dalam penyelesaian masalah waris.

Pada saat Belanda datang ke Indonesia, yang bertujuan berdagang, juga membawa hukumnya sendiri yaitu hukum Eropa, sehingga pada waktu itu hukum Islâm, hukum adat, dan hukum Eropa (BW) berlaku secara berdampingan dalam masyarakat, tanpa campur tangan dari pemerintah Belanda.

Pada tahun 1855, pemerintah Hindia Belanda memberikan perhatiannya kepada hukum Islâm, yaitu dengan dikeluarkannya Regeringsreglement (Staatsblad 1855 Nomor 2). Dalam Staatsblad tersebut, hal yang terkait dengan hukum Islâm adalah pasal 75 ayat 3, 4 ,dan 5, yang secara berurutan adalah sebagai berikut:

Selain dari apa yang telah dinyatakan berlaku bagi penduduk asli seperti yang termaksud di atas atau dimana penduduk asli 
itu sendiri yang telah menyatakan tunduk kepada hukum perdata dan hukum dagang golongan Eropa, maka hakim Bumi Putera harus memperlakukan kebiasaan (adat), undang-undang peraturan agama, instelling penduduk asli sejauh tidak bertentangan dengan azas-azas kepatutan dan keadilan yang diakui umum;

Dengan peraturan (undang-undang) agama, instelling dan kebiasaan (adat) itu pulalah hendaknya hakim Eropa (Raad Van Justitie) memutus perkara (gevonnisd) kepala-kepala penduduk asli yang tunduk kepada pengadilan tingkat ini dan juga perkara yang diajukan bandingnya atas putusan hakim Bumi Putera mengenai perkara perdata dan dagang;

Hakim Eropa sejauh mungkin memperlakukan undang-undang (peraturan) agama, instelling dan kebiasaan (adat) itu apabila tergugat dihadapkan kepadanya adalah seorang penduduk asli karena sesuatu hal dalam perkara perdata dan dagang ....2

Dari isi pasal 75 ayat 3, 4, dan 5 tersebut nampak bahwa pemerintah Hindia Belanda dengan peraturannya yang tertulis, mengakui keberadaan hukum Islâm bagi masyarakat Indonesia yang beragama Islâm.

Sebenarnya dikeluarkannya peraturan tentang berlakunya hukum Islâm bagi penduduk asli Indonesia yang beragama Islâm adalah akibat dari teori receptio in complexu. Teori ini menyatakan bahwa hukum Islâm berlaku sepenuhnya bagi orang Islâm di Indonesia walaupun terdapat penyimpangan. ${ }^{3}$ Pemerintah Hindia Belanda pada waktu itu memberikan pengakuan atas hukum Islâm.

Pada perkembangannya, pemerintah Hindia Belanda menganggap bahwa penyebaran agama Islâm menghambat usahanya dalam menguasai seluruh wilayah. Sejalan dengan usaha tersebut timbul teori Receptie, yang menentang teori Receptio in complexu. Teori ini menyatakan bahwa hukum yang berlaku untuk orang Islâm bukan hukum Islâm melainkan hukum adat dan hukum Islâm baru menjadi hukum apabila diterima oleh hukum adat. ${ }^{4}$

\footnotetext{
2 Sajuti Thalib, Receptio Acontrario, Hubungan Hukum Adat Dengan Hukum Islam (Jakarta : Bina Aksara 1982), hlm. 25.

${ }^{3}$ Ibid., hlm. 26.

4 Ibid. hlm. 23.
} 
Teori Receptie ini mendapat perhatian dari pemerintah Hindia Belanda. Hukum Islâm yang telah menjadi jiwa masyarakat Islâm di Indonesia berangsur mulai dirubah. Perubahan itu ditujukan pada pasal 75 RR di atas yang dianggap menguntungkan bagi orang Islâm di Indonesia. Pada tahun 1906 dengan Staatblad 1907-204 kata 'memperlakukan godstientige wetten (peraturan) agama" diperlunak dengan diganti kata "diikuti". Selanjutnya dengan Staatblad 1916-621 kata "diikuti" diganti dengan "memperhatikan". Dengan demikian terjadi dua kali perlunakan terhadap berlakunya hukum Islâm di Indonesia. Sejak saat itu, maka apabila terjadi sengketa perdata sesama orang yang beragama Islâm akan diselesaikan oleh hakim agama Islâm sepanjang hukum adat mereka menghendaki dan tidak bertentangan dengan ordonantie. ${ }^{5}$

Setelah jaman kemerdekaan, alam pikiran masyarakat yang menganut teori receptie masih banyak. Golongan ini mempertahankan teori tersebut dengan menggunakan pasal II Aturan Peralihan Undang-Undang Dasar 1945, yang menyatakan bahwa ketentuan yang telah ada tetap berlaku sepanjang belum diganti.

Selain golongan yang mempertahankan teori receptie di atas, masih terdapat golongan lain yang menyatakan hal yang sebaliknya. Dasar yang dipakai oleh golongan ini adalah Pembukaan UndangUndang Dasar 1945. Golongan ini menyatakan bahwa isi pasal 134 ayat 2 IS dihubungkan dengan Pembukaan jo. pasal 29 ayat 2-nya, maka akan dapat ditarik kesimpulan bahwa isi pasal 134 ayat 2 IS bertentangan dengan peraturan yang tertinggi di negara kita.

Dengan demikian dapatlah disimpulkan bahwa dasar berlakunya hukum Islâm di Indonesia adalah Pembukaan UndangUndang Dasar 1945 khususnya pada alinea keempat, yang di dalamnya terdapat rumusan Sila Ketuhanan Yang Maha Esa dan pasal 29 ayat 2 . Pasal 29 ayat 2 inilah yang dapat dijadikan landasan bagi ummat Islâm untuk menggunakan segala ajaran atau syarî́at agamanya, termasuk di dalamnya untuk menggunakan hukum waris Islâm dalam menyelesaikan masalah waris.

Kewenangan Peradilan Agama dalam Menangani Perkara Waris Sebelum Berlakunya Undang-Undang Nomor 3 Tahun 2006

${ }^{5}$ Ibid. 
Jika kita membicarakan masalah kewenangan peradilan agama dalam perkara waris maka tidak dapat dipisahkan dengan politik dan sejarah yang melantarbelakanginya. Pada awalnya, bangsa Belanda yang bertujuan berdagang ke Indonesia, tidak mempengaruhi keberadaan hukum Islâm yang telah ada. Malahan pada tahun 1855 dibentuk pengadilan agama yang berwenang menangani masalah perkawinan, waris dan wakaf. Tetapi setelah VOC digantikan dengan pemerintah penjajah yang sebenarnya, pemerintah Belanda mengganggap ajaran agama Islâm sebagai penghalang dalam menjalankan politik hukumnya ${ }^{6}$ sehingga dikeluarkanlah Staatblaat 1937-116 yang menyatakan bahwa wewenang pengadilan agama saat itu dipersempit dan masalah waris menjadi kewenangan pengadilan negeri (Landraad).

Setelah merdeka, jika dibandingkan kewenangan pengadilan agama (baca: Mahkamah Syar'iah) di luar Jawa dan Madura adalah lebih luas dibandingkan dengan kewenangan pengadilan agama di Jawa dan Madura.

Kendati demikian, walaupun pengadilan agama khususnya di Jawa dan Madura sejak tahun 1937 secara formal tidak berwenang lagi menerima perkara waris yang diajukan oleh pihak-pihak, tetapi pengadilan agama diperbolehkan memberikan fatwâ waris. Secara hukum fatwâ waris dari pengadilan agama tidak mempunyai kekuatan hukum yang mengikat, artinya meskipun dalam suatu perkawa waris sudah dimintakan fatwâ kepada pengadilan agama, namun pihak-pihak dapat memperkarakan kembali ke pengadilan negeri.

Walaupun sejak tahun 1937, wewenang pengadilan agama dalam bidang waris sudah dicabut, namun dalam praktik kehidupan masyarakat tertentu, pengadilan agama lebih banyak menangani perkara waris dibandingkan dengan pengadilan negeri. Hal ini menunjukan bahwa hukum waris Islâm dan eksistensi pengadilan agama tidak dapat begitu saja dihilangkan dari lingkungan masyarakat Indonesia.

Secara hukum penyelesaian waris di pengadilan agama sebelum berlakunya Undang-Undang Nomor 7 Tahun 1989, tidak

\footnotetext{
6 A. Rachmad Budiono, Pembaharuan Hukum Kewarisan Islam di Indonesia (Bandung: Citra Aditya Bakti, 1999), hlm. 1.
} 
efektif karena hanya berupa fatwâ. Namun, hal yang patut dipertanyakan adalah mengapa masyarakat senantiasa menghadap ke pengadilan agama dan tidak sekedar meminta nasihat melainkan ada juga yang meminta putusan. Jawaban atas pertanyaan ini lebih terkait dengan kondisi dan sikap masyarakat sendiri dibandingkan dengan faktor yuridis. Adapun kondisi dan sikap masyarakat itu, antara lain, adalah: Pertama, pada umumnya masyarakat, terutama di Jawa dan Madura, tidak menganggap adanya masalah kewenangan hukum, yaitu bahwa pengadilan negerilah yang berwenang untuk memutuskan persengketaan waris dan masih banyak orang terutama golongan menengah ke bawah berpendapat bahwa pengadilan agama sebagai tempat untuk menyelesaikan perkara perkawinan dan pengadilan negeri sebagai tempat untuk perkara pidana. ${ }^{7}$ Kedua, pada umumnya mesyarakat tidak terbiasa dengan prosedur-prosedur resmi, sehingga lingkungan sosial dan agama sangat berpengaruh dalam memilih pengadilan mana yang akan dimintai bantuan hukum. ${ }^{8}$ Ketiga, karena pengadilan agama dalam menyelesaikan masalah waris lebih bersifat kekekuargaan, lebih cepat dan lebih murah jika dibandingkan dengan penyelesaian di pengadilan negeri. Jarang sekali pengadilan agama memerlukan waktu yang lama untuk menyelesaikan perkara waris yang diajukan pihak-pihak, sebab pada umumnya di antara mereka tidak ada persengketaan. Hal ini jauh berbeda dengan perkara waris yang diajukan ke pengadilan negeri, yang memerlukan waktu yang relatif lama, apalagi jika ada pihak yang tidak puas akan putusan yang diberikan sehingga masih dimintakan upaya banding atau kasasi.

Pada tanggal 29 Desember 1989, pemerintah mengundangkan Undang-Undang Nomor 7 Tahun 1989 yaitu Undang-Undang tentang Peradilan Agama. Salah satu tujuan diundangkannya undang-undang tersebut adalah agar terdapat kesatuan hukum, baik dalam sisi peraturan hukum yang mendasarinya maupun dalam hal kewenangan. Di dalam pasal 49 secara tegas diatur tentang kewenangan pengadilan agama pada waktu itu, yaitu memeriksa, memutus, dan menyelesaikan perkara pada tingkat pertama atara

\footnotetext{
7 Zaini Ahmad Noeh, Peradilan Agama Islam di Indonesia: Studi Tentang landasan Politik Lembaga-Lembaga Hukum (Jakarta : Intermasa, 1980), hlm. 263.

8 Ibid.
} 
orang-orang yang beragama Islâm di bidang perkawinan, kewarisan, wasiat, dan hibah yang dilakukan berdasarkan hukum Islâm serta wakaf, dan sadaqah.

Berdasarkan Undang-Undang Nomor 7 Tahun 1989, khusus dalam masalah waris, pengadilan agama berwenang memutus dan putusannya mempunyai kekuatan mengikat seperti halnya putusan pengadilan negeri. Namun walaupun sudah secara tegas telah dinyatakan bahwa masalah waris antara orang yang beragama Islâm merupakan kewenangan pengadilan agama, di dalam Penjelasan Umum butir 2 alinea ke-6 dinyatakan bahwa para pihak sebelum berperkara dapat mempertimbangkan untuk memilih hukum apa yang akan digunakan dalam pembagian warisan. Dari kata "dapat" tersebut dapatlah ditarik kesimpulan bahwa para pihak boleh melakukan pilihan hukum, apakah mereka akan memilih hukum waris Islâm, hukum waris adat, ataupun hukum waris Barat (BW).

Dalam pasal 62 ayat 1 Undang-Undang Nomor 7 Tahun 1989 menyatakan bahwa segala penetapan dan putusan pengadilan selain harus memuat pasal-pasal tertentu dalam peraturan perundangundangan atau sumber hukum tak tertulis yang dijadikan dasar untuk mengadili. Dari isi pasal tersebut dapatlah ditarik kesimpulan bahwa hukum tidak tertulis dapat dipergunakan dasar di dalam pengadilan agama memberikan putusan. Bila pasal tersebut tidak dibatasi, maka bukan hukum Islâm saja yang dapat diterapkan sebagai dasar pengambilan putusan, tetapi juga meliputi ketentuanketentuan lain yang ada dalam pergaulan masyarakat, misalnya hukum adat. Bila semua hukum yang hidup dapat diterapkan dalam pengadilan memutus perkara waris, maka hal ini bertentangan dengan pasal 49 ayat (3) di mana dinyatakan bahwa pengadilan agama di dalam setiap pengambilan putusan dalam perkara waris senantiasa menerapkan hukum waris Islâm.

Apabila hal tersebut di atas terjadi maka diperlukan pertimbangan dari pengadilan agama agar tidak menjadikan pasal 62 ayat (1) sebagai satu-satunya landasan yurudis, melainkan harus pula memperhatikan faktor-faktor non yuridis, misalnya faktor sosiologis, sehingga pengadilan agama tidak dapat menerima begitu saja perkara yang diajukan oleh para pihak apabila hukum yang dipilih selain hukum Islâm. Bila hal itu terjadi maka pengadilan agama dapat memberikan nasihat kepada para pihak bahwa jika mereka 
menginginkan masalah warisnya diselesaikan menurut hukum selain Islâm, maka sebaiknya perkara itu diajukan ke pengadilan negeri. Namun pengadilan agama dapat juga menyarankan bahwa apabila pihak-pihak memang sepakat untuk membagi waris berdasarkan hukum selain Islâm, maka pengadilan agama dapat menyelesaikan perkara tersebut dengan hukum waris Islâm (merupakan hasil kesepakatan atau musyawarah). Jadi, hasil musyawarah inilah yang dapat dikategorikan sebagai pilihan hukum berdasarkan pasal 62 ayat (1) Undang-Undang Nomor 7 Tahun 1989.

\section{Azas Personalita Keislaman dalam Hukum Waris}

Jauh sebelum disahkannya Undang-Undang Nomor 7 Tahun 1989, luas jangkauan peradilan agama sebenarnya mengadili perkara-perkara waris bertitik tolak dari azas keislaman, walaupun hal di atas hanya meliputi di luar Jawa dan Madura. Tetapi apabila dihubungkan dengan ketentuan pasal 2 Undang-Undang Nomor 7 Tahun 1989,9 maka sangatlah jelas bahwa salah satu azas sentral dalam undang-undang tersebut adalah personalitas keislaman. ${ }^{10}$

Azas personalitas keislaman dijadikan sebagai dasar penegakan eksistensi peradilan agama di mana di dalam Penjelasan pasal 10 Undang-Undang Nomor 14 Tahun 1970 tentang Kekuasaan Kehakiman (yang kemudian dirubah dengan Undang-Undang Nomor 4 Tahun 2004), kekhususannya terletak pada redaksi "golongan rakyat tertentu". Yang dimaksud golongan masyarakat tertentu itu dijelaskan lebih lanjut dalam pasal 2 jo. Pasal 49 ayat 1 Undang-Undang Nomor 3 Tahun 2006.11

\footnotetext{
${ }^{9}$ Isi pasal 2 menyatakan bahwa peradilan agama merupakan salah satu pelaksana kekuasaan kehakiman bagi rakyat pencari keadilan yang beragama Islâm mengenai perkara perdata tertentu.

10 Azas personalita keislaman artinya seseorang yang tunduk atau yang dapat ditundukan pada hukum Islâm, yakni mereka yang memeluk agama Islâm. Selain itu azas tersebut mengandung pengertian bahwa hanya pada bidang-bidang hukum tertentu saja. Lihat M.Yahya Harahap, Kedudukan Kewenangan dan Acara Peradilan Agama (Jakarta : Sinar Grafika, 2001), hlm.147.

11 Adapun kewenangan pengadilan agama sebagai pengadilan tingkat pertama, bagi orang-orang yang bergama Islâm, menurut pasal 49 ayat 1 tersebut antara lain: perkawinan, waris, wasiat, hibah, wakaf, zakat, infaq, shadaqah, dan ekonomi syari'ah.
} 
Namun walaupun di dalam pasal-pasal tersebut sudah secara eksplisit dinyatakan kewenangan pengadilan agama untuk memeriksa dan memutus perkara waris orang-orang yang beragama Islâm, namun di dalam pelaksanaannya banyak menghadapi kendala, baik dari sisi lembaga pengadilan maupun masyarakat pada umumnya. Pada kenyataannya, masyarakat lebih banyak memilih menyelesaikan persoalan warisnya di pengadilan negeri, yang tentu saja tidak menerapkan hukum waris Islâm.

Sebenarnya tidak diterapkannya hukum waris Islâm dalam sengketa waris antara orang-orang yang beragama Islâm adalah akibat adanya hak opsi12. Dengan adanya hak opsi ini, maka hukum waris merupakan bidang yang sifatnya hanya mengatur (reglen) dan tidak bersifat memaksa (dwingend). Karenanya azas personalitas keislaman yang sebenarnya menjadi dasar berlakunya hukum waris Islâm bagi orang yang beragama Islâm dapat disingkirkan melalui persetujuan/kesepakatan dari pihak-pihak yang bersengketa. Terkadang hukum waris Islâm disimpangi dengan alasan yang lain, misalnya bahwa hukum waris Islâm mengandung cacat tersembunyi terutama dalam masalah portie (pembagian) antara anak laki-laki dan anak perempuan.

Problema adanya hak opsi dalam hukum waris tidak hanya terdapat pada tataran hukum waris materiil, tetapi juga pada hukum acara. Ketika pihak-pihak yang bersengketa tidak dapat mencapai kata sepakat untuk menentukan hukum waris yang akan dipergunakan dalam menyelesaikan suatu sengketa waris, maka kemungkinan satu sengketa waris diperiksa oleh 2 (dua) peradilan yang berbeda dan akan menerapkan hukum waris yang berbeda pula, yaitu pengadilan agama dan pengadilan negeri sebagai pengadilan

\footnotetext{
12 Hak opsi adalah hak memilih hukum yang dirasa cocok dengan seseorang dan biasanya bidang-bidang hukum yang memiliki hak opsi adalah bidang hukum perdata. Dengan hak opsi, undang-undang memberikan kesempatan kepada para pihak yang bersengketa untuk memilih hukum waris yang dianggap adil di antara hukum waris yang berlaku di Indonesia. Karena termasuk ke dalam ruang lingkup hukum perdata, hakim tidak dapat menentukan hukum apa yang akan diterapkan. Dengan demikian hak opsi dalam waris tidaklah bertentangan dengan azas hukum perdata. Namun jika ditinjau dari sudut pandangan hukum Islâm, hal tersebut berbeda karena dengan hak opsi seolah-olah menomorduakan hukum agama.
} 
tingkat pertama. Bila hal ini terjadi, maka akan tidak memberikan kepastian berlakunya hukum di masyarakat.

\section{Kewenangan Peradilan Agama dalam Menangani Perkara Waris} Setelah Berlakunya Undang-Undang Nomor 3 Tahun 2006

Dalam kehidupan bermasyarakat dan bernegara, idealnya suatu hukum dapatlah mengikuti perkembangan jaman sehingga hukum yang berlaku dapat juga menyelesaikan persoalan. Salah satu perubahan atas Undang-Undang Nomor 7 Tahun 1989 adalah kewenangan pengadilan di lingkungan peradilan agama yang diperluas, yang dituntut oleh perkembangan hukum dan kebutuhan masyarakat, khususnya masyarakat muslim. Salah satu perubahan yang fundamental adalah masalah waris bagi orang-orang yang beragama Islâm. Dalam Penjelasan Undang-Undang Nomor 3 Tahun 2006, dimana redaksi tentang hak opsi dalam pembagian waris dinyatakan dihapus. Dengan demikian pengadilan agama sebagai pengadilan tingkat pertama mempunyai kewenangan memeriksa, memutus dan menyesaikan perkara waris antara orang-orang yang beragama Islâm. Hal ini menunjukan bahwa dengan Undang-Undang yang baru ini, kedudukan hukum peradilan agama lebih kuat daripada sebelumnya.

Selanjutnya yang menjadi pertanyaan besar adalah; pertama, mampukah Undang-Undang Nomor 3 Tahun 2006 berlaku secara efektif? Di mana hukum waris Islâm benar-benar dapat diterapkan pada sengketa hukum waris antar orang yang beragama Islâm? Berdasarkan hasil penelitian pada tahun 2001, yakni 12 tahun setelah berlakunya Undang-Undang Nomor 7 Tahun 1989, di Pengadilanpengadilan Surabaya, Malang, Madiun, Jember, dan Pamekasan menunjukan bahwa tingkat pendayagunaan atau pemanfaatan pengadilan agama masih sangat rendah. Prosentase hasil penelitian menunjukan bahwa perkara waris Islâm yang diajukan ke pengadilan agama sangatlah minim, dan para pihak lebih banyak yang memperkarakan ke pengadilan negeri. ${ }^{13}$

Kedua, apakah dengan berlakunya Undang-Undang Nomor 3 Tahun 2006 tersebut, hak opsi bagi orang yang beragama Islâm sudah

\footnotetext{
${ }^{13}$ Afdol, Penerapan Hukum Waris Islam Secara Adil (Surabaya: Airlangga University Press, 2003), hlm. 22.
} 
tidak ada lagi, sehingga mau tidak mau haruslah menggunakan hukum waris Islâm? Untuk menjawab pertanyaan yang kedua ini haruslah dengan pikiran yang jernih dan bersih. Menurut hemat penulis, selama pihak-pihak sepakat untuk tidak menggunakan hukum waris Islâm yang menjadi kewenangan pengadilan agama, hal tersebut masih dapat dibenarkan, dengan syarat tidak terdapat pihakpihak yang dirugikan akibat kesepakatan tersebut. Hal ini mengacu pada prinsip musyawarah yang dijunjung tinggi dalam hukum Islâm, sehingga kesepakatan tersebut juga termasuk dalam koridor hukum Islâm. Namun sebaliknya, jika tidak terdapat kesepakatan, pihakpihak haruslah tunduk pada hukum waris Islâm.

Hal tersebut didasarkan pada logika hukum bahwa kedaulatan pihak-pihak yang berkepentingan dapat dianggap ada terutama dalam hukum perjanjian. Sedangkan dalam hukum keluarga, perkawinan, dan waris, pengaruh kemauan sendiri pihakpihak yang berkepentingan sangatlah kurang. ${ }^{14}$

Dengan pendekatan teori ilmu hukum, terdapat hubungan yang erat antara peristiwa hukum dan aturan hukum. ${ }^{15}$ Waris yang timbul akibat kematian seseorang, merupakan peristiwa hukum dan bukan perbuatan hukum, karena orang yang telah meninggal tidak dapat melakukan perbuatan hukum. Dengan demikian, agama pewarislah yang dapat dijadikan dasar untuk menentukan hukum waris apa yang akan diterapkan.

\section{Penutup}

Walaupun Undang-Undang Nomor 3 Tahun 2006 mengisyaratkan bahwa hukum waris Islâm mengikat dan berlaku bagi orang-orang yang beragama Islâm, dalam kenyataannya belum memenuhi harapan, karena ternyata ada sebagian anggota masyarakat yang belum menundukkan diri pada hukum waris Islâm. Selain faktor sejarah politik devide et impera Hindia Belanda, yang telah dijelaskan sebelumnya, ternyata juga disebabkan oleh faktor ketidakpahaman sebagian masyarakat tentang waris Islâm dan terutama tentang kewenangan peradilan agama dalam mengadili dan memutus perkara waris. Karenanya perlu ditingkatkan lagi

\footnotetext{
14Wirjono Prodjodikoro, Hukum Adat Golongan (Bandung: Sumur, 1985), hlm. 44.
}

15Satjipto Raharjo, Ilmu Hukum (Bandung: Alumni, 1986), hlm. 35. 
sosialisasi hal tersebut kepada masyarakat. Pemahaman tersebut, tentu saja, haruslah diupayakan secara terencana dan intensif, dengan harapan agar pada masa yang akan datang, hukum waris Islâm selalu dipergunakan dalam menyelesaikan masalah waris bagi masyarakat muslim di Indonesia. Wallâh a'lam bi al-shawâb.

\section{Daftar Pustaka}

Afdol. Penerapan Hukum Waris Islam Secara Adil. Surabaya: Airlangga University Press, 2003.

Afdol dan Kamilah, Lilik. "Pola Pembagian Waris berdasarkan Permohonan di Pengadilan Agama Surabaya dan Malang", Yuridika, Vol. 14 No. 1 (Januari-Pebruari, 1999).

Noeh, Zaini Ahmad. Peradilan Agama Islam di Indonesia: Studi Tentang landasan Politik Lembaga-Lembaga Hukum. Jakarta: Intermasa, 1980.

Budiono, A. Rachmad. Pembaharuan Hukum Kewarisan Islam di Indonesia. Bandung: Citra Aditya Bakti, 1999.

Harahap, M.Yahya. Kedudukan Kewenangan dan Acara Peradilan Agama. Jakarta: Sinar Grafika, 2001.

Prodjodikoro, Wirjono. Hukum Adat Golongan. Bandung: Sumur, 1985.

Raharjo, Satjipto. Ilmu Hukum. Bandung: Alumni, 1986.

Thalib, Sajuti. Receptio A Contrario, Hubungan Hukum Adat dengan Hukum Islam. Jakarta: Bina Aksara 1982. 